\title{
MulawarmanLawReview
}

Volume 5 Issue 1, June 2020

\section{Marine Litter Management Policy: State Responsibilities And The Role Of Local Wisdom}

\author{
Yohanes Hermanto Sirait, Ai Permanasari \\ Faculty of Law, Maranatha Christian University, Indonesia. \\ E-mail: yohanessirait1988@gmail.com
}

\begin{abstract}
Indonesia as the biggest maritime state has not only advantages but also obstacles in managing sea. Called potential because of its large resources but it also brings into a fact of the lack in exploitation of the sea. Such transportation and exploitation have caused a lot debris in the sea which is harmful. This article aims to examine state responsibility in prevent and tackle marine debris. It also aims to enhance local wisdom as solution. This article is normative juridical, using statute and conceptual approach. It is made deductive from specific issue into general issue based on primary, secondary, and tertiary legal materials. After collecting all material, this article then analyzes it qualitatively. The result show that state responsibility has been implemented only in level of regulation. Although some regulation has underlined local wisdom as important matter, in fact, Indonesia still in process of inventory related local wisdom and still far from enhancing the local wisdom as solution to prevent and tackle marine debris. These practices are different to some states which apply their local wisdom as one of solution. Therefore, Indonesia must collaborate legal policy and local wisdom to achieve higher result in preventing and tackling marine littering. A legal policy that born from the way of life in community may accepted better.
\end{abstract}

Keywords: State Responsibility; Local Wisdom; Marine Littering.

Citation: Sirait, Yohanes Hermanto, and Ai Permanasari. 2020. "Marine Litter Management Policy: State Responsibilities And The Role Of Local Wisdom". Mulawarman Law Review 5 (1), 18-28. https://doi.org/10.30872/mulrev.v5i1.307.

\section{INTRODUCTION}

International recognition has given to Indonesia as the largest archipelago in the world. The reason is simple because Indonesia has vast seas, including territorial seas and an extensive Exclusive Economic Zone ${ }^{1}$. The recognition is not only given verbally but contained in a legal document called the United Nations Convention on the Law of the Sea (UNCLOS). The international agreement is the most extensive marine law product in the world and is recognized by the majority of countries in the world.

Besides being rich in marine resources, the geographical position of the Indonesian archipelago is very strategic because it is the center of maritime traffic between

${ }^{1}$ Ridwan Lasabuda. (2013). Pembangunan Wilayah Pesisir dan Lautan dalam Perspektif Negara Kepulauan Republik Indonesia. Jurnal IImiah Platax, Vol. I-2, p. 92. 
continents (global maritime axis). ${ }^{2}$ This condition also made the President of the Republic of Indonesia, Ir. Joko Widodo, wants to develop culture and economy in the maritime sector as presented at the East Asia Summit Meeting in November $2014 .^{3}$ The vision of Indonesia will make Indonesia a sovereign, developed, independent and robust nation while contributing to peace and security at the ASEAN and world levels. ${ }^{4}$

The big desire above is certainly not easy to realize. It takes the participation of every element of the country, such as the legislature, executive, judiciary, and the community itself. This is further complicated because taking care of a sea that is so large will take a lot of energy, thought, and cost. Indonesia can learn from several other countries such as neighboring Singapore or countries in parts of Europe, such as Britain and Norway. Positive things from the level of substance, structure, and legal culture of some of these countries can be emulated, but by not leaving the life values of the Indonesian nation, Pancasila. The Pancasila philosophy, which is extracted from the values that live in the community, remains the foundation of legal policy.

Among the many issues relating to the Indonesian sea, one important issue is with regard to marine resources and sea security. It cannot be denied that almost every year, cases of fish theft by foreign vessels occur in Indonesia. ${ }^{5}$ Furthermore, the issue of the right to exploit the sea by fishermen and residents around the sea coast is still incomplete until now. Based on this experience later, Former Minister of Maritime Affairs and Fisheries, Susi Pudjiastuti, urged Indonesia to bring the issue of special rights at sea or sea rights to the international level so that it would be of concern to the international community.

The issue of sea rights has become important because seeing the practice of human activities at sea has placed the sea solely as an object rather than an equal subject. In addition to large-scale exploitation of the sea, another issue is related to the practice of dumping waste into the sea. The World Economic Forum in 2016 noted that there were more than 150 million tons of plastic in the planet's oceans. Every year, 8 million tons of plastic flow into the sea.

Every year, 8 million tons of plastic flow into the sea. Though plastic can be hundreds of years old in the ocean and break down into small particles in a much longer time. Plastic will accumulate over and over at sea. ${ }^{6}$ Specifically for Indonesia, the latest data

\footnotetext{
2 Ibid, p.93

${ }^{3}$ Dewi Santoso, Fadhillah Nafisah. (2017). Indonesia's Global Maritime Axis Doctrine: Security Concerns and Recommendations. Jurnal Hubungan Internasional, Tahun X, No.2, p. 87

${ }^{4}$ lbid.

${ }^{5}$ The Indonesian Ministry of Maritime Affairs and Fisheries, through the Director General of Maritime and Fisheries Resources Supervision, said that his team had captured 38 fishing vessels from January to April 11, 2019. "The number consists of 15 Foreign Fish Vessels (KIA) Vietnam, 13 KIA Malaysia, and 10 Indonesian Fishing Vessels (KII)". See, Caesar Akbar, "KKP Tangkap 38 Kapal Pencuri Ikan Sepanjang 2019", https://bisnis.tempo.co/read/1194945/kkp-tangkap-38-kapal-pencuri-ikan-sepanjang-2019/full\&view=ok, accessed on December 19, 2019,

6 Danu Damarjati, "Data mengerikan soal sampah plastik di lautan", https://news.detik.com/berita/d4315147/data-mengerikan-soal-sampah-plastik-di-lautan, accessed on January 13, 2020.
} 
from the Ministry of Maritime Affairs and Fisheries (KKP), plastic waste that pollutes the Indonesian ocean reaches 1.29 million metric tons (M / T). ${ }^{7}$

Article 33 paragraph (3) of the 1945 Constitution does state that the earth, water and everything contained therein is controlled by the state, however, the word "controlled" literally is certainly not the same as "owned". If the interpretation is wrong, the impact is like what is happening now, sea marine littering continues to grow and increasingly pollutes the sea. The word should also be interpreted as preserved and preserved. Thus the state will be responsible for ensuring the sustainability of the sea and play an active role in preventing and overcoming marine waste.

The above efforts to prevent and deal with marine marine littering must become a sustainable legal and political policy from the highest to the lowest elements of the country, involving all stakeholders. Furthermore, the core of the legal policy must be to place the sea in a central position while simultaneously being the subject of marine activities. In addition, legal policies must also spread not only at the national level but at the international level, considering that sea use will also not be separated from other countries' activities.

The practice of bringing national discourse to the international level has been carried out by Indonesia through the Djuanda Declaration. The declaration emphasized Indonesia's position as an archipelagic nation while at the same time encouraging the international community to give a special place to the archipelagic state concept. This practice can be repeated by Indonesia when it encourages the strengthening of sea rights on the international scene. This can be started by departing from the issue of a large buildup of marine marine littering. Indonesia can again bring local issues (local wisdom) to the national and international levels. The implementation can indeed be different for each region because of the different forms of local wisdom. It is precisely here that state responsibility is needed to keep all local wisdom practices within the framework of the Republic of Indonesia (NKRI).

\section{METHOD}

This research or writing is normative juridical research, which is legal research that puts the law as a norm system building. The norm system in question is about the principles, norms, rules of the laws and regulations, agreements, and doctrines (teachings). ${ }^{8}$ Research is analytical descriptive, that is, describing legal events from general to specific matters. ${ }^{9}$ Furthermore, the research approach used is the statutory approach and conceptual approach. The first approach is used to see the rule of law both at international and national levels, while the conceptual approach is used to look at concepts and theories in studying and answering legal problems.

\footnotetext{
${ }^{7}$ Moh. Kadafi, "Miris, Sampah Plastik di Laut Indonesia Mencapai 1,29 Juta Metrik Ton", merdeka.com, accessed on Januari 10, 2020.

8 Mukti Fajar, Yulianto Achmad. (2010). Dualisme Penelitian Hukum Normatif \& Empiris, Yogyakarta: Pustaka Pelajar, p. 34 \& 51.

${ }_{9}^{9}$ Amirudin dan Zainal Asikin. (2006). Pengantar Metode Penelitian Hukum, Jakarta: Raja Grafindo Persada, p. 10.
} 
The type of data used in this paper is secondary data consisting of primary legal materials, secondary legal materials, and tertiary legal materials. ${ }^{10}$ Primary legal material in the form of legislation from the highest to the lowest hierarchy as long as it is still relevant in this paper and is also supplemented with legal material derived from international conventions or treaties relating to the state and the sea. Secondary legal material consists of books, articles in journals and others. Finally, tertiary legal material consists of dictionaries and encyclopedias.

In order to collect data, this paper uses literature studies through the collection of reference materials both in printed and e-book forms. The reference material is then analyzed deductively to get a specific main idea.

Furthermore, this paper is not intended to target one or several existing local wisdom. Because of its normative and not empirical nature, this paper aims to examine the rules and norms not to evaluate individual practices of local wisdom but rather to see how the state should be responsible for seeking to prevent and control plastic waste. For this reason, local wisdom is used as one method in addition to other methods.

\section{DISCUSSION}

\section{State Responsibility to the Environment and the Sea}

Indonesia, as a sovereign state, has full power or authority over all matters within the territorial jurisdiction of Indonesia. Such concepts of sovereignty are recognized worldwide and form the solid foundation of a nation either individually or in an interconnected context. ${ }^{11}$ Sovereignty can refer to domestic sovereignty, interdependence, international law sovereignty, and absolute sovereignty. ${ }^{12}$

Sovereignty belongs to a country, not to a state official. This practice is often misunderstood as if the state officials were the holders of sovereignty. Similarly, the concept of people's sovereignty cannot be interpreted so narrowly, as the people themselves are one element of nation-building beyond the other three elements. One element to note is that the region itself contains the sea as part of the territory that forms a country. This means that even in the seaside, there is sovereignty. In other words, the sea is as sovereign as the governments and sovereign people.

The process of state activity is indeed represented by the government but must be based on accountability and accountability. For this reason, the country is required to take responsibility for its territory, including the sea. The concept of state responsibility is important here. There are 2 (two) perspectives that can be used when looking at national responsibilities, first, with respect to the obligation of the state to take responsibility for violations of international law and second, the commitment to protect its citizens and territories from potential violations. ${ }^{13}$ For the second

\footnotetext{
${ }^{10}$ Bambang Sunggono. (2012). MetodologiPenelitian Hukum, Jakarta: Raja Grafindo Persada, p. 113.

${ }^{11}$ Sigit Riyanto. (2012). Kedaulatan Negara dalam Kerangka Hukum Internasional Kontemporer, Yustisia, Vol.1 No. 3, p. 6 .

12 Ibid.

13 Sompong Sucharitkul. (1996). State Responsibility and International Liability Under International Law, Loyola of Los Angeles Int'I. \& Comp. L.J. 821, p. 823.
} 
perspective, if interpreted in the context of this article then there is an obligation of the state to guarantee the protection of the territory of the sea from any threat or violation, including disposal of waste into the sea.

In the context of the country responsible for the environment, the state must at least guarantee the utilization of natural resources that enrich the community while balancing the sustainability of the situation through the prevention of environmental degradation. ${ }^{14}$ Given the content of this article, the country is responsible for the utilization of the sea in view of the safe sea conditions of the waste. The responsibility is made through the efforts of prevention and protection of marine littering.

\section{Local Wisdom as a State Responsibility in the Prevention and Treatment of Marine Littering}

The world in which we live is not only made up of humans but must be supported by biotic and abiotic factors. Without the support of a good environment, the world cannot be said to be a decent place for living beings. In order to maintain a good and sustainable future, it must be focused on the living and the living environment. It fits into the paradigm of the organ system or the ecological paradigm, which views the universe as a living system. The universe is not a tool or machine that can be exploited for the benefit of mankind, but should be treated and treated with respect in the cooperation and mutual support of the life of the universe. We cannot say that it is the most important human being, such as the anthropocentric paradigm, that leads to human liberty in treating the universe. ${ }^{15}$ When that happens, nature will be destroyed by human exploitation and destructive behavior. Without the existence of nature, human beings would also be destroyed.

The notion that posits the Right to Nature holds that humans must stop treating nature as an object or property, and change their perception of nature. One milestone in the movement of natural or environmental rights was in 1972, the Southern California Law Review published an article from Christopher D. Stone, "Should trees have standing - towards legal rights for natural objects." 16 Stone described how, under the existing legal structure, nature is considered to have no rights or legally does not have rights that can be defended and upheld. In further developments, although it took a long time, around 46 years from the first time it was sparked, several countries in the world began to recognize nature as the holder of rights and gave legal standing to nature or the environment (Legal Standing) to appear as a petitioner in court. ${ }^{17}$

There has been an awareness that between nature and humans have interdependent and interrelated relationships, and the sustainability of the lives of future generations

14 Sudi Fahmi. (2011) Asas Tanggung Jawab Negara Sebagai Dasar Pelaksanaan Perlindungan dan Pengelolaan Lingkungan Hidup. Jurnal Hukum, No. 2, Vol. 18, p. 226

15 A. Sonny Keraf. (2014). Filsafat Sebagai Lingkungan Hidup: Alam Sebagai Sebuah Sistem Kehidupan, Yogyakarta: Kanisius, p. 14

${ }^{16}$ Community Environment Legal Dafense Fund, https://celdf.org/advancing-community-rights/rights-ofnature/rights-nature-timeline/, accesed on January 15, 2020.

17 Megan Barickman, Rights of Nature: A Few Theoretical Considerations, https://www.earthlawcenter.org/blog-entries/2018/1/rights-of-nature-a-few-theoretical-considerations, accessed on April 20, 2020 
of humans depends on environmental protection. Humans, rivers, forests, animals, and plants share the right to life. ${ }^{18}$ When recognizing the rights of nature, there must be restrictions on the use of nature, to maintain the balance of the ecosystem. For example, cutting down trees may be needed to build houses, but to meet those needs, then we destroy forests or destroy animal species, but instead have a negative effect on humanity, we may not see this effect on our generation, but future generations will feel the impact, ${ }^{19}$ likewise with the fact that human activities on this earth have produced enormous waste and pollute the oceans and living things in them. For example, plastic is produced for the benefit of human life, but the quality that makes plastic useful - lightweight, durable, strong, flexible, and low-cost production - now causes a global crisis of ocean pollution that is increasingly mounting. It is estimated that around 300 million tons of plastic are produced each year. ${ }^{20}$ Currently, there are 150 million tons of plastic in the world's oceans. This number will increase by another 250 million if the trends of urbanization, production, and consumption continue. $A$ report from the World Economic Forum and Ellen MacArthur Foundation estimates that by 2050 there will be more plastic than fish (by weight) in the ocean unless there are efforts to deal with it. ${ }^{21}$ Indonesia itself is ranked second after China, as the largest contributor to marine litter. ${ }^{22}$

Considering that Indonesia's territory consists of 77 percent of the ocean, of course, the sea is very important for Indonesia. The sustainability of the sea is something that must be fought by Indonesia. Indonesia has pioneered the protection of the sea, as proposed by the Minister of Maritime Affairs and Fisheries of the Republic of Indonesia for the period 2014-1019, Susi Pudjiastuti, that the sea must be given rights, just as humans have human rights, the sea also has rights. This proposal was first presented at the Marine Conference held by the United Nations (UN) called the UN Ocean Conference in New York in June 2017. ${ }^{23}$ Ocean Rights or Ocean rights is a new framework that seeks to create a balance between humans and the ocean, and new standards and criteria for conservation. Sea Rights require humans to treat the oceans as fellow members of the Earth community, rather than merely being a resource for consumption. Ocean rights can be an evolutionary and innovative solution, which is needed to create a climate of change in marine conservation. This right is also translated into state obligations as stipulated in the Basel Convention on the Control of

\footnotetext{
18 David R. Boyd. (2017). The Rights of Nature: A Legal Revolution That Could Save the World. Canada: ECW Press, 2017, p. 221

$19 \mathrm{lbid}$, p. 214

${ }^{20}$ Gourmelon, G, "Global Plastic Production Rises, Recycling Lages, Vital Signs, World Watch Institute", 2015, dikutip di World Bank Group. Hotspot Sampah Laut Indonesia. (2018). Laporan Sintesis. p. 1

${ }^{21}$ World Economic Forum, Ellen Mac Arthur Foundation, dan McKinsey \& Company. (2016). "The new plastics economy: Rethinking the future of plastics. Accessed at http://www3.weforum.org/docs/WEF The New Plastics Economy.pdf, on April 17, 2020.

22 Ocean Conservancy and the McKinsey Center for Business and Environment. (2015). Stemming the tide: Land-based strategies for a plastic-free ocean. New York: McKinsey and Company, p. 8-10.

${ }^{23}$ Angga Aliya ZRF, "Susi Bawa Usulan 'Hak Asasi Laut' ke Konferensi Kelautan Eropa”, Detik Finance, 2017. https://finance.detik.com/berita-ekonomi-bisnis/d-3670903/susi-bawa-usulan-hak-asasi-laut-ke-konferensikelautan-eropa, accessed April 15, 2020.
} 
Transboundary Movements of Hazardous Wastes and their Disposal and MARPOL Annex V (Convention on Prevention of Pollution from Ships). ${ }^{24}$

At the international level, Indonesia also stated its commitment to overcoming the issue of marine waste. As promised by the government at the G20 Meeting in Germany in 2017, Indonesia has issued a national policy related to the sea. This policy can be interpreted as a big commitment from the Indonesian people, but still, a policy on paper without action is not enough. ${ }^{25}$

Although the proposal to treat the sea as a subject was put forward at the international level, in practice this has been done at the local level. Some countries have successfully applied local wisdom in preventing and overcoming waste so that it becomes a model that many other countries emulate. Japan, for example, is famous for its local wisdom and culture in sorting waste. This method developed in several countries so that a model called zero waste emerged. ${ }^{26}$ This concept is inseparable from the efforts of $3 \mathrm{R}$ (reduce, reuse, and recycle), which are also known in many countries, including Indonesia.

The concept of reduction, reuse, and recycling is easy to say but difficult to do. For a developing country character like Indonesia with a large population, this is increasingly difficult to do. This is also the reason why Indonesia became 1 of the 3 largest marine waste producers in the world after China and before the Philippines. Here the responsibility of the state is emphasized. The state must be able to apply $3 R$ as part of the reduction and control of marine waste to every level in society.

One effort that needs to be done is to strengthen waste management in each region or at the local level. Waste that has accumulated into the sea is mostly caused by activities in the sea or around the coast. Fishing, shipping, and recreation activities contribute to a significant number of marine marine littering problems. For this reason, legal and non-legal policies need to be carried out simultaneously, bearing in mind the character of the community, which is difficult to follow the rule of law.

Legal policies of regulation, licensing, supervision, and imposition sanctions, while nonlegal procedures in the way of social movements that lead to a lifestyle. Especially nonlegal policies, in some countries, there is a zero-waste movement. This movement was first known in New Zealand and was first campaigned in 2000 by Warren Snow. This campaign then became viral and spread in the internet world so that an international

${ }^{24}$ At the national level, Law No. 32 of 2014 concerning Maritime Affairs. Specifically in Article 55 which regulates the obligations of the government (central and regional) in preventing and overcoming sea damage. Furthermore Article 56 regulates the responsibility of the state in preventing, reducing and controlling the marine environment.

25 Beatrice Garcia, et.al. (2019). Marine Plastic Pullution in Asia: All Hands-on Deck!. Chinese Journal of Environmental, Vol. 3, Issue 1, p. 32-33.

${ }^{26}$ Generally in Indonesia, waste is only distinguished from organic and inorganic waste. Japan, the waste grouping has differences, namely the criteria for garbage that can be burned (moerugomi), garbage that cannot be burned (moenaigomi) and large waste consisting of tools electronics etc. Furthermore, in Japan there is also a calendar that explains the schedule for waste disposal for each criterion. Thus, not all waste criteria can be disposed of on the same day. This method is proven to make Japan one of the waste free countries in the world. See, Japan Interstudy Center Indonesia, https://jic.co.id/sistem-pembuangan-sampah-di-jepang, accessed on April 20,2020. Also, https://www.cnnindonesia.com/internasional/20151105084240-134-89591/menengok-pengolahan-sampahdunia-dari-israel-hingga-jepang 
alliance was formed to encourage a lifestyle without waste (Zero Waste International Alliance). At present, the concept of zero waste is used as a standard at the local, national, and international levels. ${ }^{27}$ This shows how ideas originating from a small town then expanded into a lifestyle in many countries and even in Indonesia.

Currently, there is Zero Waste Indonesia, which is a One-Stop Solution platform for zero waste lifestyle that tries to spread its ideas to the people of Indonesia (accessible at zero-waste.id). If we refer to the material delivered from this lifestyle, we can actually find similarities with the lifestyle of the local community that has been going on so far, even though with different names or terminology. There are many local wisdoms in Indonesia whose values are lived in and run by various levels of society, especially traditional society. This local wisdom essentially has the same function and purpose as the lifestyle that is transmitted from the ideas of other nations.

In some areas, local wisdom has been proven to play a role in preserving the environment. Call it the sabuk gunung (Java), ngais gunung (Sundanese), sasi (Maluku), ombo (lindu) and several other areas. ${ }^{28}$ Specifically, to prevent waste accumulation, one of the local wisdoms that can be applied as done in Nagekeo Regency is the use of environmentally friendly materials in making household appliances. ${ }^{29}$ In addition, existing waste can be reused or recycled as has been done in several regions in Indonesia. ${ }^{30}$

Local wisdom above certainly will not survive if only at the sociological level. As a rule of law that prioritizes the rule of law, it is the responsibility of the state to provide legal policy as a reinforcement of local wisdom. This is the mandate of Article $18 \mathrm{~B}$ paragraph (2) of the 1945 Constitution, which recognizes and respects the customary law community units and their traditional rights. Furthermore, it is also mandated in Article 63 paragraph (1) of Law no. 32 of 2009 concerning the recognition of local wisdom related to environmental protection and management.

The government also issued Minister of Environment and Forestry Regulation Number P.34 / MENLHK / SETJEN / KUM.1 / 5/2017 concerning Recognition and Protection of Local Wisdom in the Management of Natural Resources and the Environment. Thus juridically, reinforcement has been carried out on the local wisdom. But unfortunately, so far, the new Permen mandate is limited to an inventory of local wisdom. The inventory process is carried out solely to ensure that relevant local wisdom is still legally registered. Whereas local Kearfian is not just living on paper but must live as a lifestyle for the community. Moreover, it is necessary to understand the original character of Indonesia, which in certain cases, is more subject to customary law than

\footnotetext{
27 Neil Seldman, "Zero Waste: A Short History and Program Description", islr.org, accessed April 24, 2020.

${ }_{28}$ Marhaeni Ria Siombo. (2011). Kearifan Lokal dalam Perspektif Hukum Lingkungan. Jurnal Hukum, No. 3, Vol. 28, p. 441-442.

${ }^{29}$ Although many facilities are derived from the use of plastic materials in making plates, glass, containers and others, in Nagekeo District, the equipment is made using eco-friendly materials such as woven bamboo. See, Markus Makur, "Gelas Bambu dan Wati, Kearifan Lokal Nagekeo untuk Kurangi Sampah Plastik", Kompas.com, accessed on April 20,2020.

30 Aminudin. (2019). Pemanfaatan Sampah Plastik Menjadi Kerajinan Tangan Guna Meningkatkan Kreatifitas Warga Sekitar Institut Teknologi dan Bisnis Ahmad Dahlan (ITB-AD) Jakarta. Jurnal Abdimas BSI, Vol. 2, No. 1, p. 66-79.
} 
national law. The state is responsible for encouraging local wisdom to become a lifestyle in each region as the zero waste lifestyle originating from a small village in New Zealand then extends to many other countries.

Indonesia, in essence, has a different character from other countries due to the existing cultural pluralism, the strengthening of local wisdom of each region is more acceptable. In addition, the implementation must remain in the same frame and standardization and following applicable laws. Because local wisdom in each region is different from values that are also more or less different, cooperation and sharing of information need to be carried out between the central government and the regions by involving community tokok, especially traditional and religious leaders. In addition, local wisdom in the form of environmentally friendly industries needs to be supported by technology and financing. Imports products that are not environmentally friendly need to be controlled, including local production, which is far from environmentally friendly. Thus the state has carried out its responsibilities to the environment and society while protecting local wisdom by utilizing local wisdom as a way of protecting the environment, especially the sea from the abundance of marine debris.

\section{CONCLUSION}

The concept of state responsibility in the context of the environment is not only limited to responsibilities towards other countries and responsibilities to citizens but also a responsibility to the environment. With the development of the idea that the environment can be subject to law, the state can be held liable if the environment is polluted. The sea, as part of the environment that is polluted due to the accumulation of marine littering needs further attention. Commitment to preventing and overcoming marine waste must be implemented more than just in a regulated stage but must also be a best practice that is transformed into a legal culture. Local wisdom regarding environmental protection and management can be used as a solution in the prevention and response of marine marine littering. The state must be responsible for ensuring that local wisdom is spread into a social movement and even lifestyle as zero waste has become a lifestyle in many countries. For this reason, the state needs to strengthen local wisdom through legal policy instruments and assistance in any form of environmentally friendly local wisdom. The integration of laws and regulations from the highest level to the lowest level needs to be done. Higher (central) regulations must ensure lower (regional) rules to prioritize local wisdom while still referring to a unit whose size has been determined by the state so that each local wisdom is not sectoral in nature.

\section{REFERENCES}

A. Sonny Keraf. (2014). Filsafat Sebagai Lingkungan Hidup: Alam Sebagai Sebuah Sistem Kehidupan, Yogyakarta: Kanisius.

Angga Aliya ZRF. (2017). Susi Bawa Usulan 'Hak Asasi Laut' ke Konferensi Kelautan Eropa", Detik Finance. https://finance.detik.com/berita-ekonomi-bisnis/d-3670903/susi- 
bawa-usulan-hak-asasi-laut-ke-konferensi-kelautan-eropa, [diakses pada tanggal 15 April 2020, pukul 10.00 WIB].

Aminudin. (2019). Pemanfaatan Sampah Plastik Menjadi Kerajinan Tangan Guna Meningkatkan Kreatifitas Warga Sekitar Institut Teknologi dan Bisnis Ahmad Dahlan (ITB-AD) Jakarta", Jurnal Abdimas BSI, Vol. 2, No. 1. DOI: https://doi.org/10.31294/jabdimas.v2i1.4515.

Amirudin dan Zainal Asikin. (2006). Pengantar Metode Penelitian Hukum, Jakarta: Raja Grafindo Persada.

Bambang Sunggono. (2012). Metodologi Penelitian Hukum, Jakarta: Raja Grafindo Persada.

Beatrice Garcia, et.al. (2019). Marine Plastic Pullution in Asia: All Hands-on Deck!". Chinese Journal of Environmental, Vol. 3, Issue 1. DOI: https://doi.org/10.1163/24686042-12340034

Caesar Akbar. (2019). KKP Tangkap 38 Kapal Pencuri Ikan Sepanjang 2019", https://bisnis.tempo.co/read/1194945/kkp-tangkap-38-kapal-pencuri-ikansepanjang-2019/full\&view=ok, [diakses pada tanggal 19 Desember 2019, pukul. 11.37 WIB.]

Community Environment Legal Dafense Fund. (2016). https://celdf.org/advancingcommunity-rights/rights-of-nature/rights-nature-timeline/, [diakses pada tanggal 15 Januari 2020, pukul 13.00 WIB.]

Danu Damarjati. (2018). Data mengerikan soal sampah plastik di lautan, https://news.detik.com/berita/d-4315147/data-mengerikan-soal-sampahplastik-di-lautan, [diakses pada tanggal 13 Januari 2020, pukul 14.00 WIB.]

David R. Boyd. (2017). The Rights of Nature: A Legal Revolution That Could Save the World, Canada: ECW Press.

Dewi Santoso, Fadhillah Nafisah. (2017). Indonesia's Global Maritime Axis Doctrine: Security Concerns and Recommendations. Jurnal Hubungan Internasional, Tahun X, No.2. DOI: http://dx.doi.org/10.20473/jhi.v10i2.7306

Gourmelon, G. (2015). Global Plastic Production Rises, Recycling Lages, Vital Signs, World Watch Institute. dikutip di World Bank Group. (2018). Hotspot Sampah Laut Indonesia ', Laporan Sintesis.

Japan Interstudy Center Indonesia. (2018). https://iic.co.id/sistem-pembuangansampah-di-jepang, [diakses pada tanggal 20 April 2020, Pukul. 13.00 WIB.]

Marhaeni Ria Siombo. (2011). Kearifan Lokal dalam Perspektif Hukum Lingkungan. Jurnal Hukum, No. 3, Vol. 28. DOI : 10.20885/iustum.vol18.iss3.art7. 
Markus Makur. (2018). Gelas Bambu dan Wati, Kearifan Lokal Nagekeo untuk Kurangi Sampah Plastik. Kompas.com, [diakses pada tanggal 10 April 2020, pukul 15.00 WIB.]

Megan Barickman. (2018). Rights of Nature: A Few Theoretical Considerations, https://www.earthlawcenter.org/blog-entries/2018/1/rights-of-nature-a-fewtheoretical-considerations, [diakses pada tanggal 20 April 2020, pukul 14.00 WIB.]

Moh. Kadafi. (2019). Miris, Sampah Plastik di Laut Indonesia Mencapai 1,29 Juta Metrik Ton, merdeka.com, [diakses pada tanggal 10 Januari 2020, pukul. 10.00 WIB.]

Mukti Fajar, Yulianto Achmad. (2010). Dualisme Penelitian Hukum Normatif \& Empiris, Yogyakarta: Pustaka Pelajar.

Neil Seldman. (2016). Zero Waste: A Short History and Program Description, islr.org, [diakses pada tanggal 24 April 2020, Pukul 11.00 WIB.]

Ridwan Lasabuda. (2013). Pembangunan Wilayah Pesisir dan Lautan dalam Perspektif Negara Kepulauan Republik Indonesia", Jurnal Ilmiah Platax, Vol. I-2. DOI: https://doi.org/10.35800/jip.1.2.2013.1251.

Sigit Riyanto, (2012). Kedaulatan Negara dalam Kerangka Hukum Internasional Kontemporer, Yustisia, Vol.1 No. $3 . \quad$ DOI: https://doi.org/10.20961/yustisia.v1i3.10074.

Sompong Sucharitkul. (1996). State Responsibility and International Liability Under International Law", Loyola of Los Angeles Int'l. \& Comp. L.J. 821. https://digitalcommons.Imu.edu/ilr/vol18/iss4/6.

Sudi Fahmi. (2011). Asas Tanggung Jawab Negara Sebagai Dasar Pelaksanaan Perlindungan dan Pengelolaan Lingkungan Hidup, Jurnal Hukum, No. 2, Vol. 18. DOI: https://doi.org/10.20885/iustum.vol18.iss2.art4.

World Economic Forum, Ellen Mac Arthur Foundation, dan McKinsey \& Company (2016), The new plastics economy: Rethinking the future of plastics. New York: McKinsey and Company. 